\title{
Are women different from men in ways that matter? Maybe
}

Nancy A. Nussmeier, MD

See related article on page 343.

From the Division of Cardiovascular Anesthesiology, The Texas Heart Institute at St. Luke's Episcopal Hospital, and Baylor College of Medicine, Houston, Tex.

Received for publication Oct 21, 2005; accepted for publication Oct 27, 2005.

Address for reprints: Nancy A. Nussmeier, MD, Division of Cardiovascular Anesthesiology, The Texas Heart Institute at $\mathrm{St}$ Luke's Episcopal Hospital, PO Box 20345, MC 1-226, Houston, TX 77225-00345 (Email: nnussmeier@heart.thi.tmc.edu).

J Thorac Cardiovasc Surg 2006;131:264-5

$0022-5223 / \$ 32.00$

Copyright (๑) 2006 by The American Association for Thoracic Surgery

doi:10.1016/j.jtcvs.2005.10.032

T $\mathrm{n}$ this issue of the Journal, Toumpoulis and colleagues ${ }^{1}$ report the results of their study comparing 2598 men with 1162 women in terms of the demographic and perioperative factors that predict long-term (5-year) postoperative survival after coronary artery bypass grafting (CABG). The presentation of data is unusual in its emphasis on the number of independent predictors in one gender versus the other. Although there were more predictors in men, twice as many men as women were studied, making the statistical tests performed on the men's data more powerful than those performed on the women's data. Therefore, the reported gender differences in the absolute number of predictors may be merely a statistical artifact. Also, cause of death was not captured, so it is possible that many of the reported deaths were not related to cardiovascular disease.

Whether female gender is a risk factor for short- or long-term mortality after cardiac surgery is a subject of ongoing debate. In a recent study of 15,440 patients, ${ }^{2}$ female gender independently predicted higher in-hospital mortality even when all comorbidities were taken into account (eg, age, emergency or urgent status, associated valvular surgery, prior cardiac surgery, congestive heart failure, history of cerebrovascular accident, renal insufficiency). In contrast, another large study used propensity-modeling techniques to show that female gender was not associated with increased in-hospital mortality in well-matched patients. ${ }^{3}$

Studies of the influence of gender on long-term mortality after cardiac surgery have also yielded results that are subject to interpretation. In one such study, mortality was significantly higher in women than in men 15 years after CABG, but this sex difference was largely attributable to the women's higher in-hospital mortality. ${ }^{4}$ Another study noted that unadjusted mortality was significantly higher in women than in men at 30 days and at 2 years after CABG; however, once the investigators adjusted for baseline comorbid disease, there were no sex-related differences at 2 years. ${ }^{5}$ Furthermore, in several recent studies, adjustment for women's greater number of baseline comorbidities yielded the surprising result that 5 -year post-CABG survival was actually better in women than in men. ${ }^{6-8}$

Surgical factors undoubtedly play a critical role in determining short- and long-term mortality in patients undergoing CABG. For example, the use of internal thoracic artery grafts significantly reduces mortality in patients of both sexes, ${ }^{9,10}$ but the benefit is particularly great for women. A study in which graft patency was assessed angiographically 1 year after CABG showed nonsignificant trends toward more vein graft occlusion in women $(16.7 \%)$ than in men $(12.4 \%)$, whereas internal thoracic artery graft occlusion was similar in both genders (3.4\% in women vs $5.7 \%$ in men). ${ }^{11}$ Other studies have noted lower in-hospital mortality in women who underwent off-pump surgical revascularization than in women treated with on-pump surgery. ${ }^{12,13}$ However, data addressing the long-term results of off-pump surgery are not yet available.

In the United States, women live an average of 5.2 years longer than men. ${ }^{14}$ It may be that a woman who undergoes CABG surgery is at greatest risk for mortality during the perioperative period; if she can survive this period, she should live as long as (if not longer than) a man. Nevertheless, once discharged from the hospital, women apparently have a more difficult recovery than do men in terms of their rate of persistent symptoms and hospital re-admission. ${ }^{15}$

Rather than simply counting the number of demographic and perioperative factors that predict post-CABG mortality in each gender, future studies should attempt to critically examine the gender-specific effects of surgical techniques (eg, 
internal thoracic artery grafting, off-pump surgery) and the management of perioperative risk factors (eg, high preinduction heart rates, hemodilutional anemia, transfusions, hyperglycemia, postoperative mechanical ventilation, and deep vein thrombosis) on outcomes. Furthermore, to optimize long-term recovery and survival for both women and men, gender-related differences in recovery, such as participation in cardiac rehabilitation and need for hospital readmission, should be studied. ${ }^{16}$ Only then will we continue to improve the surgical outcomes of our ever more challenging female patients.

\section{References}

1. Toumpoulis IK, Anagnostopoulos CE, Balaram SK, Rokkas CK, Swistel DG, Ashton RC Jr, et al. Assessment of independent predictors for long-term mortality between women and men after coronary artery bypass grafting: Are women different from men? J Thorac Cardiovasc Surg. 2006;131:343-51.

2. Blankstein R, Ward RP, Arnsdorf M, Jones B, Lou YB, Pine M. Female gender is an independent predictor of operative mortality after coronary artery bypass graft surgery: contemporary analysis of 31 midwestern hospitals. Circulation. 2005;112:I323-7.

3. Koch CG, Khandwala F, Nussmeier N, Blackstone EH. Gender and outcomes after coronary artery bypass grafting: a propensity-matched comparison. J Thorac Cardiovasc Surg. 2003;126:2032-43.

4. Davis KB, Chaitman B, Ryan T, Bittner V, Kennedy JW. Comparison of 15-year survival for men and women after initial medical or surgical treatment for coronary artery disease: a CASS registry study. Coronary Artery Surgery Study. J Am Coll Cardiol. 1995;25:1000-9.

5. Brandrup-Wognsen G, Berggren H, Hartford M, Hjalmarson A, Karlsson T, Herlitz J. Female sex is associated with increased mortality and morbidity early, but not late, after coronary artery bypass grafting. Eur Heart J. 1996;17:1426-31.
6. Abramov D, Tamariz MG, Sever JY, Christakis GT, Bhatnagar G, Heenan AL, et al. The influence of gender on the outcome of coronary artery bypass surgery. Ann Thorac Surg. 2000;70:800-5.

7. Guru V, Fremes SE, Tu JV. Time-related mortality for women after coronary artery bypass graft surgery: a population-based study. $J$ Thorac Cardiovasc Surg. 2004;127:1158-65.

8. Jacobs AK, Kelsey SF, Brooks MM, Faxon DP, Chaitman BR, Bittner $\mathrm{V}$, et al. Better outcome for women compared with men undergoing coronary revascularization: a report from the bypass angioplasty revascularization investigation (BARI). Circulation. 1998;98:1279-85.

9. Kurlansky PA, Traad EA, Galbut DL, Singer S, Zucker M, Ebra G. Coronary bypass surgery in women: a long-term comparative study of quality of life after bilateral internal mammary artery grafting in men and women. Ann Thorac Surg. 2002;74:1517-25.

10. O'Connor GT, Morton JR, Diehl MJ, Olmstead EM, Coffin LH, Levy DG, et al. Differences between men and women in hospital mortality associated with coronary artery bypass graft surgery. The Northern New England Cardiovascular Disease Study Group. Circulation. 1993; 88:2104-10.

11. Tan ES, van der Meer J, Jan de Kam P, Dunselman PH, Mulder BJ, Ascoop CA, et al. Worse clinical outcome but similar graft patency in women versus men one year after coronary artery bypass graft surgery owing to an excess of exposed risk factors in women. The CABADAS Research Group of the Interuniversity Cardiology Institute of The Netherlands. J Am Coll Cardiol. 1999;34:1760-8.

12. Brown PP, Mack MJ, Simon AW, Battaglia S, Tarkington L, Horner $\mathrm{S}$, et al. Outcomes experience with off-pump coronary artery bypass surgery in women. Ann Thorac Surg. 2002;74:2113-9.

13. Mack MJ, Brown P, Houser F, Katz M, Kugelmass A, Simon A, et al. On-pump versus off-pump coronary artery bypass surgery in a matched sample of women: a comparison of outcomes. Circulation. 2004;110:II1-6.

14. Kochanek KD, Murphy SL, Anderson RN, Scott C. Deaths: final data for 2002. Natl Vital Stat Rep. 2004;53:1-115.

15. Vaccarino V, Lin ZQ, Kası SV, Mattera JA, Roumanis SA, Abramson JL, et al. Gender differences in recovery after coronary artery bypass surgery. J Am Coll Cardiol. 2003;41:307-14.

16. Vaccarino V, Koch CG. Long-term benefits of coronary bypass surgery: are the gains for women less than for men? J Thorac Cardiovasc Surg. 2003;126:1707-11. 